\title{
A REVIEW OF LITERATURE AND COMPUTER MODELS ON EXPOSURE
}

\section{ASSESSMENT}

\author{
T. E. Butt ${ }^{\text {a }}$; M. Clark ${ }^{\text {b }}$ F. Coulon ${ }^{\text {c }}$; K. O. K. Oduyemi ${ }^{\text {d }}$
}

${ }^{\text {a }}$ School of Architecture \& Construction, University of Greenwich, London, UK

${ }^{\mathrm{b}}$ School of Built \& Natural Environment, University of Central Lancashire, Preston, UK

${ }^{c}$ Centre for Resource Management and Efficiency, Sustainable Systems Department, School of Applied Sciences, Cranfield University, Cranfield, UK

${ }^{\mathrm{d}}$ Department of Built \& Natural Environment, School of Contemporary Sciences, University of Abertay Dundee, Scotland, UK

\begin{abstract}
At the present time risk analysis is an effective management tool used by environmental managers to protect the environment from inevitable anthropogenic activities. There are generic elements in environmental risk assessments, which are independent of the subject to which risk analysis is applied. Examples of these elements are: baseline study, hazard identification, hazards' concentration assessment, risk quantification, etc. Another important example of such generic elements is exposure assessment, which is required in a risk analysis process for landfill leachate as it would in any other environmental risk issue. Furthermore, computer models are also being developed to assist risk analysis in different fields. However, in the review of current computer models and literature particularly regarding landfills, the authors have found no evidence of existence of a holistic exposure assessment procedure underpinned with a computational method for landfill leachate. This paper, with reference to the relevant literature and models reviewed, discusses the extent to which exposure assessment is absent in landfill risk assessment approaches. The study also indicates a number of factors and features that should be added to the exposure assessment system in order to render it more strategic, thereby enhancing the quantitative risk analysis.
\end{abstract}


Keywords: waste disposal sites; landfill leachate; risk analysis; risk assessment, exposure analysis, exposure assessment; literature review; computer models.

\subsection{INTRODUCTION}

\subsection{Background}

Due to the factors such as industrial revolution, escalating mass production of commodities, increased urbanisation, propagation of human population and economic growths at national and international levels, wastes are generated at a rate greater than ever before. These wastes include industrial, commercial and domestic waste streams. Although in some cases, wastes are reported of being reduced at regional level (Scottish Executive, 2004), unfortunately, on the whole, waste production is still on the increase in the UK (DoE and Welsh Office, 1995a; 1995b; Davies, 1999; DETR, 2000; Cabinet Office, 2002; DEFRA, 2003; 2005a; 2005b). Even if wastes are reduced at regional level, due to greenhouse gases / carbon emissions related to the transport of waste from the point of production to recycling facilities and outlets, in some cases could out weigh the 'green' advantage of reuse and / or recycling. For instance, its been reported that the North East's waste in the UK is being driven as far away as Wales for recycling (Ewen, 2005). Moreover, waste is the inescapable outcome of the activities which characterise human society; indeed in one sense it is an indicator of the health of modern economy (Tromans and Stiles, 2004). It can be safely said that no matter now high we move up the Waste Hierarchy (which is described below), there will always be some waste left for landfilling.

Sustainable waste management simply means managing waste by prioritising as per the Waste Hierarchy, which is shown in Figure 1 (SEPA, 1999; DETR, 2000; Wilson, 2000; DEFRA, 2005a; 2005b). This implies waste prevention is the top most priority if possible. The other priorities in 
descending order are reduction; reuse; recovery via recycling, composting, energy; and disposal, which also includes landfilling. With reference to Figure 1, it must be noticed that the landfill waste option is not only occupying a place in the last group i.e. 'Disposal' but also in the second to the last category up the Waste Hierarchy, i.e. 'Recovery'.

Having established that waste production is an inevitable characteristic of an industrial society; most of the waste produced, particularly in the UK (DETR, 2000), is generally disposed to landfills. Waste disposal to landfills, in general, is an easy and cheap waste management option. However, landfilling does raise severe environmental concerns. One reason is that during the process of waste degradation, landfills produce waste products in three phases. These are: Solid (i.e. more or less degraded waste); Liquid (i.e. leachate, which is water polluted with wastes); and Gas (usually referred to as landfill gas comprising e.g. Methane, Carbon-dioxide, Hydrogen-sulphide, etc.).

Furthermore, landfills have the potential to pollute the three principal environmental media - the atmosphere, the lithosphere and the hydrosphere. Such pollution will be transmitted through these media and will impact, either directly or indirectly, upon humans, the natural environment (including aquatic and terrestrial flora and fauna) and the built environment (Moriarty, 1993; Butt and Oduyemi, 2003). Thus, the risks associated with landfills need to be assessed and managed to guard the environment against landfill hazards, not only for humans but also other receptors including flora, fauna, water and land or soils.

On the other hand, environmental legislation are not only becoming stricter and more stringent but also have increasingly followed a global theme. Some examples of such legislation are listed below in chronological order. Some legislation are directly related to landfills (e.g. the Landfill Directive, the Waste Management Licensing Regulations, the Environmental Protection Act, etc.) while others 
indirectly. Directives cover not only the UK but also the other member states of the European Union / Community.

1. EC Directive on Groundwater (EC, 1980);

2. EC Directive on EIA (Environmental Impact Assessment) (EC, 1985);

3. Environmental Protection Act, 1990;

4. EC Directive on the Conservation of Natural Habitats and of Wild Fauna and Flora (The Habitats Directive) (EC, 1992);

5. Waste Management Licensing Regulations (SI, 1994a; 2005);

6. Environment Act, 1995;

7. EU Directive on IPPC (Integrated Pollution Control and Prevention) (EU, 1996);

8. Groundwater Regulations (SI, 1998);

9. Landfill Directive (EC, 1999);

10. Water Framework Directive, (EC, 2000);

11. Landfill Regulations (SI, 2002; 2004; 2005; Scottish Executive et. al., 2005); and

12. Strategic Environmental Assessment (SEA) Directive (ODPM, 2003)

In parallel to the growing environmental concerns and globalisation process described earlier, having realised the significance and effectiveness of risk assessment in environmental management, the environmental legislation has started to impose risk analysis as a tool for meeting legal requirements associated with waste hazards (Environment Agency, 2003a). For instance, for the protection of groundwater from landfill leachate a risk assessment exercise has been introduced in the UK as a legal requirement since 1st May 1994, through Regulation 15 of the Waste Management Licensing Regulations (SI, 1994a) and the Groundwater Regulations (SI, 1998). The Landfill Directive is implemented in England and Wales through the Landfill Regulations (SI, 2002), made under the Pollution Prevention and Control (PPC) Act (England and Wales) 1999. The 
overall aim of the Landfill Directive, which came out in 1999, is to prevent or reduce as far as possible negative impacts on the environment, in particular the pollution of surface water, groundwater, soil and air, and on the global environment, including greenhouse effect, as well as any resulting risk to human health, from the landfilling of waste, during the whole life-cycle of the landfill (CIWM, 2008). The equivalent legislation, which is called Landfill (Scotland) Regulations, has come out in Scotland (SSI, 2000; 2003; SEPA, 2005a; 2005b). The equivalent legislation has also been in place in Northern Ireland since 2003 (SR, 2003). It can be deduced from all these legislative instruments that the 'out of sight, out of mind' concept regarding wastes (i.e. simply and blindly buried into the ground and forgotten) is no longer applicable. To achieve the maximum protection of the environment against the hazards associated with landfill sites, all potential hazards must be identified and risks associated with them assessed.

A risk assessment has two main aspects which are hazard assessment and risk estimation (CIRIA, 2001). The former aspect generally focuses on identification of hazards' source, pathways and receptors / targets. Where as the latter facet is to establish how likely it is that a given hazard would reach and hit the receptor / target via the pathway. Specifically in the former context, risk analysis has been applied to a number of subjects for a long time. However, it is the latter aspect i.e. risk estimation part of risk assessment which is, comparatively, a new and rapidly growing science, particularly in relation to probabilistic and statistical approaches. Thus, on the whole risk assessment, relatively, is a new and fast developing field of study (LaGoy, 1994; Tweeds, 1996; Butt and Oduyemi, 2003). This is not just in relation to landfills and other environmental issues but also in relation to other business fields including, food industry, ecology, epidemiology, health physics, radiation, earthquakes, finance, construction management, building contract selection, insurance, economics, fire, landslides, ship navigation, and oil industry (Rejda, 1995; Tweeds, 1996; WHO, 1997; Mitchell, 1998; HSE, 1998; CIWEM, 1999; Brebbia, 2000; Butt and Oduyemi, 2000; 2003; Butt et. al., 2006a). Regardless of the type of risk assessment and the environmental 
area of application, one of the important parts of risk analysis is exposure assessment (Moschandreas et. al., 2002). In the literature review carried out by the authors (examples and further details are contained in Table 1 and Section 2.0), it was concluded that risk analysis approaches for landfill leachate do not have a holistic exposure assessment procedure aided with a computer model. A number of important elements of exposure assessment that are absent in risk analysis approaches and computer models are also discussed below.

\subsection{Definition and Terminology Implications}

Figure 2 represents overall structure of risk analysis with a range of building blocks including baseline study, hazard identification, exposure assessment, hazards' concentration assessment, pollutants' migration assessment, significance assessment, uncertainty assessment, hazard indices, and risk quantification. In the UK the term generally used is risk assessment as opposed to risk analysis which is more often referred to in the US. Therefore, the authors have noticed that both terms are used in literature interchangeably. Thus, this paper uses both risk assessment and risk analysis terms interchangeably. This also helps to cover international audience rather than only national.

The Figure shows position of exposure assessment in relation to overall risk analysis structure. The Figure also illustrates the other building blocks of risk assessment process. In the Figure, exposure assessment further branches out into its parts and sub-parts. The other building blocks are not the focus of this paper thus their parts and sub-parts are beyond the scope of this paper.

In the context of landfill risk analysis, the authors describe an exposure assessment process as that fundamental stage of a risk assessment exercise in which a given landfill i.e. the pollutant source is characterised and, pathways and environmental receptors are identified and categorised. For this, 
the basic information is to come from the baseline study module of the risk assessment where the relevant information would have already been gathered by the risk assessor (Butt and Oduyemi, 2000). Similarly, hazards / pollutants would have already been specified in the hazard identification section of the risk assessment (Butt et. al., 2006b). In exposure assessment, in addition to identification, characterisation and categorisation of the hazards' source, pathways and receptors / targets, exposures of the identified receptors to the identified hazards through identified pathways are also quantified to support the quantitative risk analysis. It is worth mentioning that the term 'holistic' in this paper implies an overall framework or system, covering all aspects and factors of the exposure assessment from the point of view of leachate.

\subsection{LITERATURE ON RISK ANALYSIS AND EXPOSURE ASSESSMENT}

Literature on risk assessment that is related to environmental issues and specifically regarding landfills has been the main focus of the review. This literature review includes, for instance, Gregory et. al., 1999; Nathanail, 2003; Bardos et. al., 2003a; 2003b; Eduljee, 1998; Redfearn et. al., 2000; DoE, 1995; and CIRIA, 2001 (See more references in Table 1). In this study not only latest but some old literature have also been considered in order to ensure if any developments on the subject were made in the far past. The review of literature clearly shows that exposure assessment is a crucial factor in an environmental risk analysis because hazards' source, pathways, and receptors have to be specified and exposures have to be measured in order to be able to establish the degree and nature of risks. The following two sub-sections explain why the development of a strategic framework of exposure assessment is necessary for landfill leachate.

\subsection{Current and Future Legislation}


Table 1 shows that the current literature (and computer models discussed in Section 3.0) regarding risk analysis and exposure assessment are just about sufficient to meet the current legislation requirements such as drinking water standards. The literature mainly considers humans as receptors. Furthermore, in terms of the development of an overall exposure assessment procedure, there is a lack of attention given to some other aspects. Some examples of such aspects are:

- Receptors other than humans, such as aquatic and terrestrial flora and fauna (like fish, crops);

- Natural and yet non-living receptors such as land / soil, air, watercourses / groundwater, etc.;

- Built environment comprising such as human-made ponds, buildings, and structures;

- Water courses other than used by humans for drinking such as rivers of various water grades (SI, 1994b); and

- Statistical descriptions for maximum and mean exposure quantification, in order to assist with measuring risks for worst case and most likely scenarios, respectively, in a risk analysis process.

The above listed areas become more important when future legislation is expected to be more stringent, inclusive and integrated (Section 1.0). For instance, the Water Framework Directive (EC, 2000) will be transposed into the UK legislation in the near future. This Directive includes new requirements for protection and restoration not only of ground waters but also surface waters and dependent ecological systems (Environment Agency, 2003a). Similarly, the Landfill Directive and Regulations take it even beyond surface and ground waters only, thereby, including air, soil, global environment, greenhouse gases, and human health on the top of surface and ground waters (EC, 1999; SI, 2002; 2004; 2005; Scottish Executive et. al., 2005). Another directive, generally referred to as Habitat Directive (EC, 1992), brings legal obligation to combat hazards in order to guard and enhance natural habitats and wild fauna and flora. On basis of these examples of legislation which are tending to be a lot more holistic than ever before, it can be concluded that an even more integrated approach towards exposure assessment and subsequently risk analysis is required. 
2.2 Non-integrated Literature on Exposure Assessment and Risk Assessment

A review of environmental related literature led to the conclusion that a comprehensive, robust, detailed and sound risk assessment methodology, with a number of essential features does not exist in an integrated manner. Examples of such essential features are listed below:

- Encompassing various types of landfill systems and their surroundings

- Taking into account all possible characteristics of landfills in terms of risks and quantification of risks posed by landfills

- Embedding procedures of relevant modules (such as baseline study, hazard identification, hazards' concentration assessment, exposure analysis, pollutants migration, etc.). Figure 2 illustrates these modules.

A number of knowledge gaps have been found in the literature reviewed to date. One of the common gaps is an integrated and computer aided procedure for carrying out exposure assessment, specifically for landfill leachate. The literature on exposure assessment to date is limited, indirect and in a piece-meal manner. The current literature accounts for different aspects of exposure analysis to different levels of detail. The publications are non-integrated and independent of each other. Some publications (such as Redfearn et. al., 2000) focus on humans as receptors and only consider inhalation exposure route, whereas other environmental species and exposure routes are excluded. Some publications emphasise certain types of hazards and not all possible hazards (for example, Moschandreas et. al., 2002 focus only on Particulate Matter (PM) hazard). In some publications, only multi-media and multi-pathway exposure and risk assessment of contamination due to an industrial facility are discussed (e.g. Bagli and Spadoni, 2000). Some publications (such as Eduljee, 1998; DoE, 1995) consider exposure analysis in a general context and focus only on 
humans as receptors. Some literature concentrate on exposure from contaminated land perspective but not specifically landfills. Further details are given in Table 1. In summary, there does not exist such an exposure assessment procedure, which allows integrated considerations of all the factors listed in (the first row of) Table 1 for all environmental receptors, both living and non-living, via all exposure routes.

\subsection{COMPUTER MODELS OF RISK ANALYSIS AND EXPOSURE ASSESSMENT}

The development of computational methods and the ability to model systems more precisely now enable hazards to be quantified, their effects to be simulated, and risk analysis to be pursued with greater accuracy. This leads to a more effective risk management. These developments are not only important for all areas of human endeavour, but have particular relevance to environmental issues where the risks involved are increasingly seen as substantial. However, no evidence of a computer model of total risk assessment, which regards the knowledge gaps indicated in Section 2.0, has been found. The case is identical in terms of computer modelling for exposure assessment alone, as discussed in detail later in this section. A computer model is seen as an electronic representation of a methodology or procedure in this paper.

The investigation of various relevant computer models during the literature review led to the identification of models that are closely related to landfill risk assessment. These models are LandSim (Environment Agency, 2003d; 2001), HELP (Scientific Software Group, 1998), GasSim (Attenborough et. al., 2002; Golder Associates, 2003), GasSimLite (Environment Agency, 2002) and RIP (Golder Associates, 1998; Landcare Research, 2003). The first four computer models were specifically designed for landfills, although the features of the RIP (Repository Integration Programme) were subsequently extended to take landfills into account on a comparatively large scale. While other software types studied are not demonstrably related to landfill risks, they could 
still be used to an extent to investigate some aspects of landfill exposure assessments and consequently risk assessments.

As far as software packages addressing landfill risk assessment are concerned they do not holistically encapsulate all elements of risk analysis methodology for landfills, including that of exposure assessment. However, some of the computer models could deal with some aspects of exposure assessment for landfills. For example, the RIP, which is an integrated probabilistic simulator for environmental systems, has been designed generally for any potential pollutant source in the ground e.g. a chemical storage tank. So with the RIP, which is a generic software model, risk assessors have to adapt it to their specific problems (such as landfills). This adaptation is time consuming and it is not an easy task for everyone (Miller, 1998). The RIP has features, which embrace source, pathway and receptor. This it does in terms of likely concentrations of hazards leaking from the source, migrating via a pathway, and reaching and entering receptors. However, the RIP does not readily provide such a straightforward exposure assessment procedure for landfill leachate where a landfill assessor could identify and categorise hazards' source (that is a given landfill), pathways (mainly exposure media) and receptors. In the same manner, it also does not readily provide for a consideration of statistical descriptions for maximum and mean exposure values.

On the other hand the LandSim model, which is purely for landfill risk assessment, does not embed all parts of a landfill risk assessment process, including that of exposure assessment. LandSim just probabilistically estimates the likely concentration of a leachate pollutant that can reach a given point in the ground (for example a groundwater abstraction point) in a certain time, in terms of years. It does not allow for the quantification of exposure such as what would be the degree of exposure for people (or livestock) if they were to consume this groundwater. Therefore, the LandSim's characteristic of pollutant concentration estimation in an exposure medium such as 
groundwater can be taken a step further to quantify exposure to, for instance, live-stock or a fish farm, which would make quantitative risk assessment more comprehensive. This way, a holistic exposure assessment methodology can be useful to further build on the information obtained from a software model such as LandSim. Similarly, HELP (Hydro-geological Evaluation of Landfill Performance) model contains only some aspects of landfill risk assessment. These are mainly the design features of landfill (such as liners and capping) and some of the baseline study aspects (like precipitation and surface runoff). However, it does not consider a very important aspect of risk assessment, that is an exposure assessment system. Although the software GasSim deals with some aspects of risk assessment modules, including gas generation, migration, impact and exposure, it is only for landfill gas and not leachate. Also, the exposure aspect regards mainly humans and atmosphere as receptors and no other environmental species are accounted for. GasSimLite is also from the perspective of landfill gas only and can be used only in terms of calculating gas emissions.

ConSim model is a tool for assessing the risks that are posed to groundwater quality by pollutants migrating from contaminated land (Whittaker et. al., 2001). The authors learnt that this is not specifically for landfills in the first place, particularly when landfills have leachate head and / or liners, which is a likely scenario with modern landfills (Environment Agency, 2003b). Also, this model does not accommodate receptors other than groundwater. The CLEA (Contaminated Land Exposure Assessment) model considers risks only to human health and not other environmental receptors such as plants, animals, buildings and controlled waters (Environment Agency, 2003c). Pathways are seen only from the perspective of soil as an exposure medium and not leachate (Environment Agency et. al., 2002). Also, this model has been developed for contaminated land and not specifically for landfills (DEFRA and Environment Agency, 2002). Other elements such as number 5 mentioned in the first row of Table 1 are absent in the model. 
SADA (Spatial Analysis and Decision Assistance) is a software that incorporates tools from environmental assessment fields into an effective problem solving environment (TIEM, 2006). These tools include integrated modules for visualisation, geo-spatial analysis, statistical analysis, human health risk assessment, ecological risk assessment, cost / benefit analysis, sampling design, and decision analysis. Out of this wide range of tools or modules, only two most possibly relevant are selected to describe here as examples. The Human Health Risk module provides a full human health risk assessment and associated databases from a range of land-use scenarios. These include residential, industrial, agricultural, recreational, and excavation but not specifically landfills. Ecological Risk is another module or unit of the SADA which allows users to perform benchmark screenings and the ability to calculate forward risk to a number of terrestrial and aquatic receptors that are currently being added. Even after this module has been fully developed, it may only be helpful to an extent to address a few aspects of landfill exposure assessments. For instance, assisting in identifying a whole range of environmental receptors (both aquatic and terrestrial) and yet for humans as receptors, the user still will have to consult the former module i.e. Human Health Risk module. SADA appears to inhouse a number of various software to address a range of different risk scenarios. Thus, a landfill assessor will have to work on picking the right combinations of these different software each time they are carrying out a landfill exposure analysis and yet SADA will not provide for each and every facet of landfill exposure assessment in a readily useable format. Moreover, as the title 'Spatial Analysis and Decision Assistance (SADA)'states, the focus appears to be more on spatial than temporal.

ARAMS (Adaptable Risk Assessment Modelling System) is a computer-based, modelling and database driven analysis system developed for the US Army for estimating the human and ecological health impacts and risk associated with military relevant compounds (MRCs) and other constituents (ERDC, 2006). ARAMS takes various existing databases and models for exposure, intake / update, and effects (health impacts) and incorporates them into conceptual site-models. The 
user may need to choose which particular model and / or database to use for each scenario. The heart of ARAMS is the object-oriented Conceptual Site Model (CSM) but that relies yet on another computer programme called FRAMES discussed below. Thus it is not an easy task to adapt ARAMS into a landfill leachate scenario every time if a landfill assessor decides to use ARAMS. Although, ARAMS appears to concentrate mostly on the exposure assessment facet of risk analysis, it does not cover all the elements indicated in Table 1 (Row 1, last column) in an algorithmic fashion, specifically for landfills. Similarly, MEPAS (Multimedia Environmental Pollutant Assessment System) is another computer-based programme which is a suite of environmental models developed to assess contaminated environmental problems for government, industrial, and international clients (PNNL, 2006a). Although, the software integrates transport and exposure pathways for chemical and radioactive releases to determine their potential impact on the surrounding environment, individuals, and populations. In the context of landfills, the situation with MEPAS is not much different than ARAMS. Both the computer programmes are not to and do not present an overall exposure assessment methodology of landfill leachate.

FRAMES (Framework for Risk Analysis Multimedia Environmental Systems) is a software platform for selecting and implementing environmental software models for risk assessment and management problems which may even include governance issues (Evangelidis, 2003). In other words, the purpose of FRAMES is to assist users in developing environmental scenarios and to provide options for selecting the most appropriate computer codes to conduct human and environmental risk management analyses (PNNL, 2006b). This program is a flexible tool and offers an overall approach to understanding how industrial activities affect humans and the environment. It incorporates models that integrate across scientific disciplines, allowing for tailored solutions to specific activities, and it provides meaningful information to business and technical managers. FRAMES is the key to identifying, analysing, and managing potential environmental, safety and health risks. Thus, FRAMES is a hugely generic programme, and yet it does not contain a software 
for landfill leachate scenario which could guide a landfill assessor to perform a landfill exposure analysis holistically including all the factors (mentioned in Row 1, Table 1) in one place.

The RESRAD is a combination of two words RESidual and RADiation (DMS, 2006), which is used as an acronym for Residual Radiation environmental analysis (Farlex, 2006). The RESRAD is a family of computer codes or modules to provide a scientifically based assessment of degree of cleanliness and to equip with useful tools for evaluating human health risk from residual contamination (EAD, 2006a). These codes or modules include (EAD, 2006a; 2006b):

1. RESRAD, for soil contaminated with radio-nuclides;

2. RESRADBUILD, for buildings contaminated with radio-nuclides;

3. RESRAD-CHEM, for soil contaminated with hazardous chemicals;

4. RESRADBASELINE, for risk assessments against measured (baseline) concentrations of both radio-nuclides and chemicals in environmental media;

5. RESRAD-ECORISK, for ecological risk assessments;

6. RESRAD-RECYCLE, for recycle and reuse of radio-logically contaminated metals and equipment; and

7. RESRAD-OFFSITE, for off-site receptor dose / risk assessment.

From the above it is obvious that none of the family members is specifically for landfill leachate, although addressing a range of various environmental issues and aspects. Even if these codes or modules are used in combination, they are not able to address all the features of exposure analysis of landfill leachate expressed in Table 1, Row 1. Furthermore, to combine these into a landfill leachate context alone would be a cumbersome task to execute each time an exposure assessment and risk analysis are performed for different landfill scenarios. For instance, RESRAD-CHEM considers nine exposure pathways including inhalation of dust and volatiles; ingestion of plant 
foods, meat, milk, soil, aquatic food and water; and dermal absorption from soil and water contact. This code may help address aspects of exposure assessment, but not all the absent elements (listed in the first row, last column, Table 1) in an integrated format. However, this code is no longer being updated (EAD, 2006c).

RISC-HUMAN 3.1, RUM and Vlier-Humaan (Van Hall Instituut of Business Center, 2000, 2001, and 2002, respectively) are another three computer models developed for exposure assessment and risk analysis, but they have been built for contaminated land and not specifically for landfills. Only humans are considered as receptor in these software. Other potential environmental receptors such as watercourses and built environment have not been taken into consideration in these software. The aggregation aspect (i.e. total exposure of the same receptor via various routes as mentioned in Point 2b, first row of Table 1) and statistical considerations (Point 5, first row of Table 1) are also absent.

In summary, the authors have come across no integrated computer model of a holistic exposure assessment procedure which could assist to execute the exposure analysis process specifically for a given landfill leachate from start to end considering a whole range of eventualities and / or scenarios. Currently available computer models lack the elements indicated in the first row of Table 1, either completely or partly. These absent elements or knowledge gaps require to be further investigated and bridged. Also, current computer models do not present such a concise exposure assessment model for landfill leachate, which as a complete unit, could readily be assembled with the format of other modules and sub-modules of the total risk assessment framework indicated in Figure 2. In parallel to the literature (Section 2.0), computer models are also available in nonintegrated manner. Thus, not only having a holistic procedure of exposure assessment but also a corresponding computer model in an integrated format, specifically for landfill leachate, which encapsulates all the absent elements (Row 1, Table 1) under one umbrella, can help perform 
quantitative exposure analysis more effectively and efficiently. Subsequently, this will assist risk analysis process.

\subsection{CONCLUDING REMARKS}

Despite having high potentials to pollute the environment, landfills are inevitable and required. Therefore, risk assessment and management is an effective tool to guard the environment against landfill hazards. However, there does not exist such an integrated methodology of landfill risk analysis along with a corresponding knowledge-based computer model, which is helpful enough to execute the process of risk assessment for landfill leachate from the start (i.e. baseline study) through exposure assessment to the end (i.e. hazard indices and risk quantification). A number of knowledge gaps have been identified in the literature reviewed to date and a holistic exposure assessment procedure accompanied with a corresponding computer model is one of them. The exposure assessment is one of the most important factors of an effective and quantitative risk analysis, as the success of the latter is based on the former.

Current literature and models are just about enough to meet the risk assessment requirements of the present environmental legislation in the UK. Future legislation is going to be more stringent and wider in scope to encapsulate more environmental species such as various food chain links, ecological systems, terrestrial and aquatic flora and fauna. Therefore a more comprehensive, concise and robust risk analysis system underpinned by more strategic exposure assessment approach will be needed. This research work assists the authors to recognise the necessity and significance of exposure assessment; and identify knowledge gaps and current models' limitations. Thereby, lay foundation for developing in future a more complete and sequential or step-by-step procedure for quantitative exposure assessment in an integrated fashion specifically for landfill 
leachate. This study may also be helpful to construct a corresponding holistic computer model of exposure analysis.

\section{ACKNOWLEDGEMENTS}

The authors acknowledge the financial support of Dundee City Council in this project. We are additionally grateful for the discussion and help received from Mr Peter Goldie of the Environment \& Consumer Protection Department, Dundee City Council. The support from Stephen T Washburn (Managing Principal, ENVIRON, New Jersey, US), Dr I. M. Spence (Consultant Environmental Geologist, Scotland), and colleagues at the University of Abertay Dundee, including $\mathrm{Mr}$ Olisanwendu Ogwuda and Mr Phillip Jenkins is also highly appreciated.

\section{REFERENCES}

1. Asante-Duah, D. K., Managing Contaminated Sites: Problem Diagnosis and Development of Site Restoration, John Wiley \& Sons Ltd., 1996

2. Attenborough, G. M.; Hall, D. H.; Gregory, R. G.; and McGoochan, L., Development of a Landfill Gas Risk Assessment Model: GasSim. In: Proceedings for Solid Waste Association of North America, 25 Annual Landfill Gas Symposium, p. 25 - 28, Monterey, California, USA, March 2002

3. Auckland Regional Council, Hazard Identification and Risk Assessment for Local Authorities Hazard Guideline No. 2, Technical Publication No. 106, Auckland Local Authority Hazard Liaison Group, (September) 2002

4. Bagli, S. and Spadoni, G., A multimedia, multiple pathway exposure and risk assessment using EHHRA-GIS: a real case of contamination due to an industrial facility; Risk Analysis II Second International Conference on Computer Simulation in Risk Analysis and Hazard Mitigation, Bologna, Italy, p. 115 - 124, 11 - 13 Oct, WIT Press, 2000

5. Bardos, P.; Nathanail, P; and Nathanail, J., How do you treat contaminated sites?, Wastes Management, p.20 - 23, CIWM (Chartered Institute of Wastes Management), September 2003a 
6. Bardos, P.; Nathanail, P; and Nathanail, J., Risk Assessment - Have you got a real problem?, Wastes Management, p.44 - 46, CIWM (Chartered Institute of Wastes Management), November 2003b

7. Bernard, Clement; Guido, Persoone; Colin, Janssen R.; and Anne, Le Dû-Delepierre. Estimation of the hazard of landfills through toxicity testing of leachates -1 . Determination of leachate toxicity with a battery of acute tests, Chemosphere, Vol 33, No. 11, p. 2303 - 2320, Elsevier Science Ltd., 1996

8. Bernard, Clement; Guido, Persoone; Colin, Janssen R.; and Anne, Le Dû-Delepierre. Estimation of the hazard of landfills through toxicity testing of leachates - 2. Comparison of physicochemical characteristics of landfill leachates with their toxicity determined with a battery of tests, Chemosphere, Vol 35, No. 11, p. 2783 - 2796, Elsevier Science Ltd., 1997

9. Brebbia, C. A. (Editor), Risk Analysis II - Second International Conference on Computer Simulation in Risk Analysis and Hazard Mitigation, Bologna, Italy, 11 - 13 Oct, WIT Press, 2000

10. Butt, T. E. and Oduyemi, K. O. K., A Holistic Approach to Concentration Assessment of Hazards in the Risk Assessment of Landfill Leachate, Environment International, Elsevier Science Ltd., Vol. 28, Issue 7, p. 597 - 608, 2003

11. Butt, T. E. and Oduyemi, K. O. K., Significance of Baseline Study in Landfill Risk Assessment, Risk Analysis II - Second International Conference on Computer Simulation in Risk Analysis and Hazard Mitigation, Bologna, Italy, p. 93 - 103, 11 - 13 Oct, WIT Press, 2000

12. Butt, T. E.; Mair, Nigel; and Oduyemi, K. O. K. Hazard Identification and Categorisation for Waste Disposal Sites: Part 1 - An integrated approach lacks, Risk Management, Vol. 8, Issue 2, p. $133-148,2006 \mathrm{a}$

13. Butt, T. E.; Mair, Nigel; and Oduyemi, K. O. K. Hazard Identification and Categorisation for Waste Disposal Sites: Part 2 - A computer-aided procedure, Risk Management, Vol. 8, Issue 3, p. $206-220,2006 b$

14. Cabinet Office, Public Attitudes Towards Recycling and Waste Management - Quantitative and Qualitative Review, Cabinet Office, (September) 2002

15. CHEM (Chemical Hazards and Emergency Management) Unit - Department of Emergency Services (Queensland Government, Australia), Carrying out a Risk Assessment for Dangerous Goods (under the Dangerous Goods Safety Management Act 2001) - DGSM Information Paper No. 6, (October) 2003

16. CIRIA (Construction Industry Research and Information Association), remedial Engineering for Closed Landfill Sites, C 557, CIRIA, London, 2001 
17. CIWEM (the Chartered Institution of Water and Environmental Management), Environmental Risk, Scottish Annual Symposium, Edinburgh Conference Centre, Organised by CIWEM Scottish Branch, (Tuesday, $16^{\text {th }}$ November) 1999

18. CIWM (Chartered Institute of Waste Management), Landfill Directive, www.ciwm.co.uk/pma/2044, CIWM, (Downloaded 17 November) 2008

19. CMSA (Chamber of Mines of South Africa), South African Mining Industry Guide to Hazard Identification \& Risk Assessment (HIRA), SA Safety Adviser's Office, 2004

20. CMSA (Chamber of Mines of South Africa), South African Mining Industry Guide to Hazard Identification \& Risk Assessment (HIRA), SA Safety Adviser's Office, 2004

21. CPPD (Cumberland Plateau Planning District), Hazard Identification \& Risk Assessment (Draft), Dewberry, (24 February) 2004

22. Daugherty, J., Assessment of Chemical Exposures - Calculation methods for environmental professionals, Lewis Publishers - CRC Press, 1998

23. Davies, Jonathan. Diversion Ahead: Which route(s) to take?, 'Wastes Management', CIWM (Chartered Institution of Waste Management), Issue: November, p. 32 - 33, 1999

24. DEFRA (Department for Environment, Food and Rural Affairs) and Environment Agency, The Contaminated Land Exposure Assessment Model (CLEA): Technical basis and algorithms, R \& D Publication CLR 10, Document prepared by the National Groundwater and Contaminated Land Centre of the Environment Agency, 2002

25. DEFRA (Department for Environment, Food and Rural Affairs), Environmental Report on Changes to Waste Strategy 2000 for the Strategic Environmental Assessment, DEFRA, (January) 2005a

26. DEFRA (Department for Environment, Food and Rural Affairs), Guidance on Municipal Waste Management Strategies, DEFRA, (July) 2005b

27. DEFRA (Department for Environment, Food and Rural Affairs), The Environment in your pocket 2003 - National Statistics, Crown Copyright, 2003

28. DETR (Department of the Environment, Transport and Regions), Waste Strategy 2000 England and Wales (Part 1), Crown Copyright, 2000

29. DETR (Department of the Environment, Transport and the Regions), Environment Agency and the Institute for the Environment and Health. Guidelines for Environmental Risk Assessment and Management. The Stationary Office, London. 2000

30. DMS (Decision Mapping System), DMS Glossary, nalu.geog.washington.edu/dms/glossary/_content.html, DMS, (Downloaded, 1 November) 2006

31. DOE (Department of Energy) US, Risk-Based Corrective Action - Environmental Guidance, DOE/EH-413-9815, DOE, 1998 
32. DOE (Department of Energy), RCRA Corrective Action - Human Health Assessment, RCRA Information Brief. EH-231-045/0594, (May) 1994

33. DoE (Department of the Environment) and the Welsh Office, Making Waste Work - Summary, HMSO, London, 1995a

34. DoE (Department of the Environment) and the Welsh Office, Making Waste Work - A strategy for sustainable waste management in England and Wales, HMSO, London, 1995b

35. DoE (Department of the Environment), The Technical Aspects of Controlled Waste Management - Health Effects from Hazardous Waste Landfill Sites, Report No. CWM/057/92, DoE, 1995

36. EAD (Environmental Assessment Division), RESRAD Program, http://www.ead.anl.gov/project/images/pa/20resrad.pdf, Argonne National Laboratory, 2006a

37. EAD (Environmental Assessment Division), RESRAD Program, http://web.ead.anl.gov/resrad/documents/anlrares.pdf, Argonne National Laboratory, 2006b

38. EAD (Environmental Assessment Division), RESRAD-Chem, http://web.ead.anl.gov/resrad/home2/chem.cfm, Argonne National Laboratory, (Downloaded, 1 November) 2006c

39. EC (European Community) Directive on EIA (Environmental Impact Assessment), (i.e. 85/337/EEC) which came into effect in July 1988, 1985

40. EC (European Community) Directive on the Conservation of Natural Habitats and of Wild Fauna and Flora (the Habitats Directive), 92/43/EEC, 1992

41. EC (European Community) Groundwater Directive, 80/68/EEC, 1980

42. EC (European Community), Landfill Directive, 99/31/EC, 1999

43. EC (European Community), Water Framework Directive, 2000/60/EC, 2000

44. Eduljee, G. H., Assessment of Risks to Human Health from Landfilling of Household Wastes, Journal: Issues in Environmental Science and Technology, Volume Title: Risk Assessment and Risk Management, Vol. 9, p. 113 - 135, 1998

45. Eisenbeis, Jhon J.; Montgomery, Robert H.; and Sanders, Thomas G. A Risk Assessment methodology for hazardous waste landfills, Geotechnical \& Geohydrological Aspects of Waste Management, $8^{\text {th }}$ Geohydro Waste Management Symposium, USA (Fort Collins), p. $417-426$, (February) 1986

46. Environment Act (EA), the Stationary Office, London, 1995

47. Environment Agency, Contaminant Impact on Groundwater: Simulation by Monte Carlo Method, ConSim Version 2, R \& D Publication 132, Golder Associates, 2003b 
48. Environment Agency, Contaminated Land Exposure Assessment (CLEA) home page, http://www. environment-agency.gov.uk/subjects/landquality/113813/274663/, Downloaded Nov. 2003c

49. Environment Agency, DEFRA (Department for Environment, Food and Rural Affairs) and SEPA (Scottish Environment Protection Agency), Contaminated Land Exposure Assessment (CLEA) Model, CLEA 2002 - Version 1.3, User Manual. Environment Agency, DEFRA and SEPA, 2002

50. Environment Agency, GasSimLite User Manual, Website: http:www.gassim.co.uk/GasSimLite/ GASSIMLT_manual_v101.pdf, Downloaded Dec. 2003, Golder Associates, 2002

51. Environment Agency, Guidance on assessment of risks from landfill sites. External consultation version 1.0, Environment Agency, Bristol. (May) 2004

52. Environment Agency, Hydrogeological Risk Assessments for Landfill and the Derivation of Groundwater Control and Trigger Levels, Environment Agency, 2003a

53. Environment Agency, LandSim 2.5 - groundwater risk assessment tool for landfill design, Environment Agency, Bristol. 2003d

54. Environment Agency, LandSim, Release 2 (V.2.02) - Landfill Performance Simulation by Monte Carlo Method, Environment Agency, R \& D Publication 120, 2001

55. Environment Agency, Procedure for identifying risks from landfills, Version 1.2, Environment Agency, (December) 2003e

56. Environmental Protection Act (EPA), the Stationary Office, London, 1990

57. Envirowise, Introduction to the Waste Hierarchy, www.imagereporting.co.uk/environment /downloads/, Crown Copyright, (May) 2005

58. EPA (Environment Protection Agency) US, Guidelines for Neurotoxicity Risk Assessment, Federal Register 63 (93):26926-26954, EPA/630/R-95/001F. Risk Assessment Forum, EPA, 1998

59. EPA (Environment Protection Agency) US, Guidelines for Reproductive Toxicity Risk Assessment, EPA/630/R-96/009, EPA, 1996a

60. EPA (Environment Protection Agency) US, Proposed Guidelines for Carcinogen Risk Assessment, EPA/600/P-92/003C, EPA, 1996c

61. EPA (Environment Protection Agency) US, Proposed Guidelines for Ecological Risk Assessment, EPA/630/R-95/002B, EPA, 1996b

62. EPA (Environmental Protection Agency) US, (Last modified March) 1999, Guidelines for Exposure Assessment, http://www.epa.gov/nceawww1/exposure.htm, FR 57, EPA/600Z92/001, EPA 
63. EPA (Environmental Protection Agency) US, Guidelines for Exposure Assessment, Federal Register No. 104, Vol. 57, EPA, 1992

64. EPA (Environmental Protection Agency) US, Hazardous Waste Identification Rule (HIWR): Identification and Listing of Hazardous of Hazardous Wastes; Notice of Data Availability and Request for Comments, Federal Register Vol. 65, No. 138, (Tuesday) 18 July, p. 44491 44506, EPA, 2000

65. EPD (Environmental Protection Department) - Hong Kong Government (Waste Facilities Development Group), Landfill Gas Hazard Assessment Guidance Note, Report Number EPD/TR8/97, EPD, 1997

66. ERDC (Engineer Research and Development Center), ARAMS, an Adaptable Risk Assessment Modelling System, US Army Corps of Engineers, http://www.erdc.usace.army.mil, (August) 2006

67. EU (European Union), adopted a directive (96/61/EU) on Integrated Pollution Prevention and Control (IPPC) in September 1996

68. Evangelidis, Adrianos. FRAMES - A Risk Assessment Framework for e-Services, Electronic Journal of e-Government, Vol. 2, Issue 1, p. 21 - 30, 2003

69. Ewen, David. 'Lancashire, Wales and Cheshire: our 'local' waste sites - We lift lid on real cost of rubbish recycling”, Evening Express, p. 4 - 5, (13 September) 2005

70. Farlex, Inc. The Free Dictionary, http://acronyms.thefreedictionary.com/RESRAD, Farlex, (1 November) 2006

71. Feldman R. G. and White R. F., Role of the Neurologist in Hazard Identification and Risk Assessment, Environ Health Perspect, Vol. 104, Suppl 2, p. 227 - 237, 1996

72. Golder Associates, GasSim - landfill gas risk assessment tool, GasSim Technical Summary (PDF Format), http://www.gassim.co.uk/GasSim_TS_final.pdf, Golder Associates, Downloaded Dec. 2003

73. Golder Associates, RIP (Repository Integration Programme) (Integrated Probabilistic Simulator for Environmental Systems), Website Location: http://www.golder.com/rip/intro.htm\#What, Golder Associates, 1998

74. Golder Associates, Risk Assessment for Small and Closed Landfills - Small and Closure Criteria, Application 4176, Golder Associates (NZ) Ltd, (December) 2002

75. Gregory, R. G.; Revans, A. J.; Hill, M. D.; Meadows, M. P.; Paul, L. and Ferguson, C. C.; A Framework to Assess Risks to Human Health and the Environment from Landfill gas, R \& D Technical Report 271, Under Contract CWM168/98, Environment Agency, 1999

76. HSE (Health and Safety Executive), Quantitative Risk Assessment for Offshore Installations Risk Management, Offshore Research Focus, No. 123, p. 76, HSE, October 1998 
77. ICE (Institution of Civil Engineers), ICE Design and Practice Guide: Contaminated Land Investigation, Assessment and Remediation, 1994

78. Jaggy, Michael. 'Risk Analysis of landfills', in Gheorghe, A.V. (Editor) Integrated Regional Health and Environmental Risk Assessment and Safety Management, published in Int. J. of Environment and Pollution, Vol. 6, Nos. 4 - 6, p. 537 - 545, Inderscience Enterprise Ltd., 1996

79. Kavazanjian, Edward Jr.; Bonaparte, Rudolph; Johnson, Gary W.; Martin, Geoffrey R. and Matasovic, Neven. Hazard analysis for a large regional landfill, Proceedings of the Geotechnical Engineering Division of the ASCE in Conjunction with the ASCE Convention, San Diego, USA. Oct 23 - 27, 1995. ASCE (American Society of Civil Engineers). 1995

80. Koivisto, Raija A., Tormakangas, Kirsi M., and Kauppinen, Veli S. Hazard Identification and Risk Assessment Procedure for Genetically Modified Plants in the Field - GMHAZID, Environmental Science \& Pollution Research, Vol. 8, Ecomed Publishers, 2001

81. LaGoy, P. K. Risk Assessment - Principles and Applications for Hazardous Waste and Related Sites, Noyes Publications, 1994

82. LaGoy, P. K., Risk Assessment - Principles and Applications for Hazardous Waste and Related Sites, Noyes Publications, 1994

83. Landcare Research (Manaaki Whenua Landcare Research - a New Zealand Crown Research Institute), Risk Assessment Model Reviews, http://www.contamsites.landcareresearch.co.nz/ risk_assessment_models_reviews.htm, 2003

84. Miller, I., Personal Communication, Golder Associates, UK, 1998

85. Mitchell, J. K., Hazards in changing cities, Applied Geology, Vol. 18, Issue 1, p 1-6, 1998

86. Moriarty, F., $2^{\text {nd }}$ Edition, Ecotoxicology: The Study of Pollutants in Ecosystems, T. J. Press (Padstow) Ltd., 1993

87. Moschandreas, D. J.; Watson, J.; D’Abreton, P.; Scire, J.; Zhu, T.; Klein, W.; and Saksena, S. Methodology of exposure modeling, Chemosphere, Vol. 49, Issue 9, p. 923 - 946, Elsevier Science, December 2002

88. Muth, Mary K.; Karns, Shawn A.; and Anderson, Donald W. Analysis of Hazard Analysis Critical Control Point (HACCP) Survey Data, Final Report - RTI Project Number 6673.008, Research Triangle Institute (RTI), (July) 2001

89. Nathanail, P and Nathanail, J.; Risk-based site characterisation, Wastes Management, p.49 - 50, CIWM (Chartered Institute of Wastes Management), October 2003

90. ODPM (Office of the Deputy Prime Minister), The Strategic Environmental Assessment Directive: Guidance for Planning Authorities - Practical guidance on applying European Directive 2001/42/EC 'on the assessment of the effects of certain plans and programmes on the environment' to land use and spatial plans in England, ODPM, (October) 2003 
91. Pauluhn, Jurgen. Hazard Identification and Risk Assessment of Pyrethroids in the Indoor Environment, Toxicology Letters, Vol. 107, p. 193 - 199, Elsevier Science Ireland Ltd., 1999

92. Peacock, W. S. and Whyte I. L. Site investigation and risk analysis, Proceeding ICE (Institute of Civil Engineers) Conference Civil Engineering 92, p. 74 - 81, (May) 1992

93. Pieper, A; Lorenz, W.; Kolb; and Bahadir, M. Determination of PCDD/F (polychlorinated dibenzo-p-dioxins and furans) for hazard assessment in a municipal landfill contaminated with industrial sewage sludge, Chemosphere, Vol. 34, No. 1, p. 121 - 129, Pergamon, 1997

94. PNNL (Pacific Northwest National Laboratory), FRAMES (Framework for Risk Analysis Multimedia Environmental Systems), PNL, http://mepas.pnl.gov/FRAMESV1/, (Last updated, 24 January) 2006b

95. PNNL (Pacific Northwest National Laboratory), Introduction to MEPAS (Multimedia Environmental Pollutant Assessment System), PNL, http://mepas.pnl.gov/mepas/index/html, (Last updated, 1 September) 2006a

96. Puncochar, Paul. The Science and Art of Identifying Workplace Hazards, Occupational Hazards, Vol. 65, Issue 9, p. 50, ProQuest, (September) 2003

97. Redfearn, A.; Roberts, R. D.; and Dockerty, J. C., Analysis and application of human health and ecological risk assessment methodologies for landfills, Proceedings Waste 2000, Waste Management at the dawn of the third Millennium, p. 455 - 464, England, 2 - 3 October 2000

98. Rejda, G. E., Principles of Risk Management and Insurance, Fifth Edition, Harper Collins College Publishers, 1995

99. Rudland, D. J.; Lancefield, R. M.; and Mayell, P. N., Contaminated Land Risk Assessment - A guide to good practice, CIRIA C552, CIRIA (Construction Industry Research and Information Association), 2001

100. Scientific Software Group, Environmental Software \& Publications (Catalogue), Washington, DC 20020 3041 , http://www.scisoftware.com/products/visual_help_details/visual_help_ details.html, 1998

101. Scottish Executive, Key Scottish Environment Statistics 2004 - A Scottish Executive National Statistics Publication, Crown Copyright, 2004

102. Scottish Executive; Welsh Assembly Government; Department of the Environment (DoE) Northern Ireland; and Office of the Deputy Prime Minister (ODPM), A Guide to the Strategic Environmental Assessment Directive, ODPM, (September) 2005

103. SEPA (Scottish Environment Protection Agency), Framework for Risk Assessment for Landfill Sites - The Geological Barrier, Mineral Layer and the Leachate Sealing and Drainage System, SEPA, (August) 2002 
104. SEPA (Scottish Environment Protection Agency), Guidance - Landfill Directive: Guidance on Monitoring of Landfill Leachate, Groundwater and Surface Water, http://www.sepa.org.uk/guidance/landfill_directive/monitoring.htm, SEPA, 2005b

105. SEPA (Scottish Environment Protection Agency), National Waste Strategy Scotland, SEPA, 1999

106. SEPA (Scottish Environment Protection Agency), SEPA Technical Guidance Note Hydrogeological Risk Assessment for Landfills and the Derivation of Control and Trigger Levels, Version 2.12, SEPA, (April) 2005a

107. SEPA (Scottish Environment Protection Agency), The Waste Hierarchy, Sustainable use of resources, www.sepa.org.uk/waste/moving_towards_zero_waste/waste_hierarchy.aspx, SEPA, (Downloaded 17 November) 2008

108. SI (Statutory Instrument), Groundwater Regulations 1998, SI No. 2746, Crown Copyright, 1998

109. SI (Statutory Instrument), Landfill (England and Wales) (Amendment) Regulations 2004, SI No. 1375, Crown Copyright, 2004

110. SI (Statutory Instrument), Landfill (England and Wales) (Amendment) Regulations 2005, SI No. 1640, Crown Copyright, 2005b

111. SI (Statutory Instrument), Landfill (England and Wales) Regulations, SI No. 1559, Crown Copyright, 2002

112. SI (Statutory Instrument), Surface Water (River Ecosystem) (Classification) Regulations 1994, SI No. 1057, 1994b

113. SI (Statutory Instrument), Waste Management Licensing (Amendment and Related Provisions) Regulations 2005, SI No. 803, 2005a

114. SI (Statutory Instrument), Waste Management Regulations 1994, SI No. 1056, 1994a

115. SITA, The Waste Hierarchy, Position paper, www.sita.co.uk/downloads/PP_WH.pdf, SITA, (August) 2004

116. SR (Statutory Rule), The Landfill Regulations (Northern Ireland), Statutory Rule No. 496, Crown Copyright, 2003

117. SSI (Scottish Statutory Instrument), Landfill (Scotland) Regulations 2003, SSI No. 235, Crown Copyright, 2003

118. SSI (Scottish Statutory Instrument), The Pollution Prevention and Control (Scotland) Regulations 2000, SSI No. 323, Crown Copyright, 2000

119. Tarazona, J. V. and Vega, M. M. Hazard and Risk Assessment of Chemicals for Terrestrial Ecosystems, Toxicology, Vol. 181 - 182, No. 0, p. 187 - 191, Elsevier Science Ireland Ltd., 2002 
120. TIEM (The Institute of Environmental Modelling), SADA (Spatial Analysis and Decision Assistance), University of Tennessee Research Corporation, http://www.tiem.utk.edu/ sada/, (Last updated, 12 June) 2006

121. TOSC (Technical Outreach Services for Communities), Human Health Risk Assessment, www.egr.msu.edu/tosc/ashland/february_17_2000/fs_risk_assessment.pdf, TOSC, 2000

122. Tromans, Stephen and Stiles, Dean. The Practical Guide to Waste Management Law, Wastes Management, CIWM (The Chartered Institution of Wastes Management), Issue: August, p. 47, 2004

123. Tweeds, Laxton's Guide to Risk Analysis \& Management, (an imprint of ButterworthHeinemann), 1996

124. Van Hall Instituut of Business Center, Software titles: RISC-HUMAN 3.1; RUM and; VlierHumaan (2000; 2001 and 2002, respectively), Leeuwarden, The Netherlands, http://www.riscsite.nl

125. Viswanathan, S.; Shah, N. and Venkatasubramanian, V. Hybrid Framework for Hazard Identification and Assessment in Batch Processes, 'AIChE (American Institute of Chemical Engineers) Journal', Vol. 48, No. 8, p. 1765 - 1774, (August) 2002

126. WDA (Welsh Development Agency), The WDA Manual on the Remediation of Contaminated Land, ECOTEC Research \& Consulting Ltd., Environmental Advisory Unit Ltd., 1994

127. Whittaker, J. J.; Buss, S. R.; Herbert, A. W. and Fermor, M.; Benchmarking and Guidance on the Comparison of Selected Groundwater Risk Assessment Models, NGACLC (National Groundwater 7 Contaminated Land Centre) Report NC/00/14, Environment Agency, Dec. 2001

128. WHO (World Health Organization), HACCP - Introducing the Hazard Analysis and Critical Control Point System, WHO, 1997 
Table 1: Literature Review Examples: Discussing elements of Exposure Assessment present and absent.

\begin{tabular}{|c|c|c|}
\hline Publication & Elements Present & Elements Absent \\
\hline ICE, 1994 & $\begin{array}{l}\text { This publication describes risk assessment from the } \\
\text { perspective of contaminated land rather than specifically } \\
\text { from landfill's point of view. This publication just outlines } \\
\text { the main contents of exposure assessment for any type of } \\
\text { contaminated land, but does not present a robust and } \\
\text { objective procedure of carrying out exposure assessment } \\
\text { for landfills or any contaminated land with items as listed } \\
\text { in the adjacent column } 3 \text { of this table. }\end{array}$ & $\begin{array}{l}\text { From the term 'elements absent' the author imply knowledge gaps and } \\
\text { limitations in the research works to date with regard to exposure } \\
\text { assessments from the perspective of landfill exposure analysis. } \\
\text { 1. There is absence of an identification and categorisation procedure } \\
\text { of pollutants at source (i.e. a given landfill), pathways (including } \\
\text { exposure medium and exposure routes such as ingestion, dermal, } \\
\text { inhalation), and receptors / targets are absent. } \\
\text { 2. (a). There is a deficiency of a system for measuring or quantifying } \\
\text { exposure of receptors to hazards, covering all possible exposure } \\
\text { routes via which hazards can possibly enter receptors' boundaries. } \\
\text { (b). There is no function or facility that allows exposures from } \\
\text { various individual exposure routes to be aggregated for a given } \\
\text { receptor exposed to a given hazard. } \\
\text { There is no consideration given to assess significance of and likely } \\
\text { uncertainties involved in the elements, particularly exposure } \\
\text { measurement, indicated above. } \\
\text { (a). Significance assessment plays a role in screening out } \\
\text { insignificant parameters e.g. which pathway and / or receptor is } \\
\text { negligible to consider in an exposure analysis process, and } \\
\text { consequently the risk assessment process. } \\
\text { (b). Whereas the uncertainty assessment assists to identify }\end{array}$ \\
\hline
\end{tabular}




\begin{tabular}{|c|c|c|}
\hline & & $\begin{array}{l}\text { uncertainties involved in measuring a parameter, for instance, } \\
\text { models' limitations, estimation methods' assumptions, data quality, } \\
\text { etc. } \\
\text { 4. There are no provisions for exposure assessment to assist with } \\
\text { measuring both worst case and most likely risk scenarios. } \\
\text { 5. The application and integration of concepts of maximum, mean and } \\
\text { minimum exposures are not included. In other words, engagement } \\
\text { of statistical descriptions that can help address issues of } \\
\text { uncertainties, and temporal and spatial variations. } \\
\text { It is not in the remit of the publication to offer a holistic computer } \\
\text { model of an integrated exposure analysis system for landfill } \\
\text { leachate which contains all the aforesaid features or elements. }\end{array}$ \\
\hline $\begin{array}{l}\text { Golder } \\
\text { Associates, } \\
2002\end{array}$ & $\begin{array}{l}\text { This publication regards risk assessment only for small and } \\
\text { closed landfills. It briefly mentions hazards and risks in the } \\
\text { context of contamination of groundwater; contamination of } \\
\text { surface water; gas accumulation; and direct exposure to } \\
\text { contaminated soil, sharp objects or hazardous gases. These } \\
\text { are the only four scenarios, which this publication } \\
\text { addresses very briefly. }\end{array}$ & $\begin{array}{l}\text { There is no strategic procedure to carry out exposure assessment process } \\
\text { in a quantitative manner for landfill leachate, which could take account } \\
\text { of all possible scenarios. There is lack of in-depth algorithmic exposure } \\
\text { quantification system that sequentially ties together the factors involved } \\
\text { such as exposure duration, frequency, exposure media and routes. In } \\
\text { summary, it is not in remit of this publication to address all the elements } \\
\text { mentioned above (in Row 1) in a holistic format specifically for landfill } \\
\text { leachate. }\end{array}$ \\
\hline CIRIA, 2001 & $\begin{array}{l}\text { This publication is only for closed landfill sites. The } \\
\text { publication contains a chapter specifically on risk } \\
\text { assessment, which also contains a brief section on exposure }\end{array}$ & There is no procedure for exposure assessment. \\
\hline
\end{tabular}




\begin{tabular}{|c|c|c|}
\hline & $\begin{array}{l}\text { assessment where main factors of exposure analysis are } \\
\text { only mentioned. }\end{array}$ & \\
\hline $\begin{array}{l}\text { Environment } \\
\text { Agency, 2003a }\end{array}$ & $\begin{array}{l}\text { Provides guideline for landfill risk assessment and only for } \\
\text { groundwater as receptor. Identifies some fundamental } \\
\text { requirements of risk assessment on, for example, geology, } \\
\text { hydrogeology, and site investigation. }\end{array}$ & $\begin{array}{l}\text { Though a guideline on landfill risk assessment exists but it is not for } \\
\text { considering receptors other than groundwater. Though this publication } \\
\text { relates to risk assessment for landfill leachate, but it is not holistic in the } \\
\text { form of a methodology or ready-to-use procedure. There are no } \\
\text { considerations of quantification of exposure and risk. The computer } \\
\text { modelling aspect of the publication (i.e. LandSim) is discussed in } \\
\text { Section 3.0. }\end{array}$ \\
\hline $\begin{array}{l}\text { DETR et. al., } \\
2000\end{array}$ & $\begin{array}{l}\text { As the document states itself that it provides material, in } \\
\text { general, for the development of risk analysis guidance to } \\
\text { assist issues like contaminated land, waste management, } \\
\text { major accident hazards. }\end{array}$ & $\begin{array}{l}\text { The publication addresses a range of issues in general (listed in the left } \\
\text { column) but not specifically for landfills or landfill leachate. The } \\
\text { objective of this publication is not to develop an integrated exposure } \\
\text { assessment to assist quantitative risk analysis. In summary, in the } \\
\text { context of landfill leachate all the elements above (Row 1) are not in the } \\
\text { remit of this publication. }\end{array}$ \\
\hline $\begin{array}{l}\text { DEFRA and } \\
\text { Environment } \\
\text { Agency, } 2002\end{array}$ & $\begin{array}{l}\text { This publication relates to exposure assessment for humans } \\
\text { from contaminated lands. Details on various aspects of } \\
\text { exposure assessment are given. Examples are exposure } \\
\text { parameters (such as exposure duration, frequency), soil } \\
\text { release and transfer mechanisms, exposure equations, } \\
\text { human activities and ages, exposure routes, various land- } \\
\text { uses. }\end{array}$ & $\begin{array}{l}\text { Deals in detail with humans as receptors, but not other environmental } \\
\text { species and eco-systems. Element number } 5 \text { above is also not there. It is } \\
\text { not specifically landfill leachate. It is for contaminated land in general. }\end{array}$ \\
\hline Environment & This document briefly addresses a broad and diverse range & A holistic exposure assessment procedure accompanied with a \\
\hline
\end{tabular}




\begin{tabular}{|c|c|c|}
\hline Agency, 2004 & $\begin{array}{l}\text { of facets of landfill risk analysis along social, technical, } \\
\text { environmental, economic, and legislative and managerial } \\
\text { themes. Both landfill gas and leachate are addressed. The } \\
\text { main scope of the guidance is limited to five areas of risk } \\
\text { analysis, which are accidents and their consequences; } \\
\text { hydrogeology; landfill gas; particulate matter; and stability. } \\
\text { The document briefly touches on elements like source, } \\
\text { pathway and receptors yet not as parts of exposure } \\
\text { assessment system. }\end{array}$ & $\begin{array}{l}\text { corresponding computer model is not in the remit of this publication. } \\
\text { There is no allowance for exposure quantification. Statistical } \\
\text { descriptions like maximum, mean and minimum exposures are not in the } \\
\text { scope either. As the document states itself that there are five main areas, } \\
\text { which constitute the main remit of the guidance (listed in the left } \\
\text { column). Yet landfill leachate is not one of them though is addressed to } \\
\text { an extent. The guidance also mentions that it does not provide all the } \\
\text { detail needed to conduct risk analysis for a landfill and the same holds } \\
\text { for exposure assessment. }\end{array}$ \\
\hline $\begin{array}{l}\text { Gregory, R. G. } \\
\text { et. al., } 1999\end{array}$ & $\begin{array}{l}\text { This publication is for risk analysis of landfill gas only. } \\
\text { Concerns mainly humans as receptors. Engages with some } \\
\text { risk assessment modules such as gas generation, human } \\
\text { exposure assessment with quantification aspect, pollutants' } \\
\text { migration. }\end{array}$ & $\begin{array}{l}\text { The risk quantification aspect is absent. It is not for landfill leachate. } \\
\text { Element } 5 \text { above is not embedded, even for landfill gas. From a leachate } \\
\text { perspective, all the aforesaid elements are absent. }\end{array}$ \\
\hline $\begin{array}{l}\text { Moschandreas } \\
\text { et. al., } 2002\end{array}$ & $\begin{array}{l}\text { Focuses on one type of hazard i.e. Particulate Matter (PM) } \\
\text { and only in air as an exposure medium. The only exposure } \\
\text { route accounted for is inhalation and considers only } \\
\text { humans as receptors. }\end{array}$ & $\begin{array}{l}\text { Does not present exposure assessment as an overall procedure and } \\
\text { specially element } 5 \text { above is not included. This publication is not } \\
\text { specifically for landfills. As mentioned in the corresponding left } \\
\text { adjacent cell, consideration of types of hazard, exposure medium, } \\
\text { exposure route, and receptor is very limited. }\end{array}$ \\
\hline $\begin{array}{l}\text { Bagli and } \\
\text { Spadoni, } 2000\end{array}$ & $\begin{array}{l}\text { This publication takes account of industrial facilities as } \\
\text { pollutant source and humans as receptors. It touches on } \\
\text { various aspects of exposure assessment including exposure } \\
\text { routes, equations and quantification. Also briefly writes }\end{array}$ & $\begin{array}{l}\text { It is not for landfills at all. Exposure assessment is not presented as an } \\
\text { overall procedure. Receptors other than humans have not been included. } \\
\text { In the context of landfill leachate all the elements mentioned above are } \\
\text { absent as well. }\end{array}$ \\
\hline
\end{tabular}




\begin{tabular}{|c|c|c|}
\hline & $\begin{array}{l}\text { about risk assessment in the light of GIS (Geographical } \\
\text { Information System). }\end{array}$ & \\
\hline $\begin{array}{l}\text { Redfearn et. } \\
\text { al., } 2000\end{array}$ & $\begin{array}{l}\text { This publication, which is a paper, is related to risk } \\
\text { assessment and thus also briefly mentions Exposure } \\
\text { Assessment. However this publication is related to landfill } \\
\text { gas and not leachate. Thus, it focuses on exposure route of } \\
\text { inhalation only. Also, it identifies some sensitivities and } \\
\text { uncertainties associated with Exposure Assessment. }\end{array}$ & $\begin{array}{l}\text { Apart from a very limited section on exposure assessment, there is no } \\
\text { procedure for describing how to perform exposure analysis process. All } \\
\text { the elements mentioned above are absent from the perspective of } \\
\text { leachate. Although the first four elements are partly addressed to an } \\
\text { extent, but the consideration is from the landfill gas perspective. }\end{array}$ \\
\hline DoE, 1995 & $\begin{array}{l}\text { This publication portrays Exposure Assessment in a } \\
\text { holistic manner, more than any other literature studied to } \\
\text { date. However, the focus is not all environmental receptors } \\
\text { but human health only. Similarly, not all potential } \\
\text { pathways have been included, but only six exposure } \\
\text { pathways which cover most risks to human health from } \\
\text { landfills. }\end{array}$ & $\begin{array}{l}\text { Does not present an exposure assessment procedure in a holistic manner, } \\
\text { in the form of a computer model, that is element number } 6 \text { (above in } \\
\text { Row 1) is absent. Does not take account of all environmental receptors } \\
\text { such as flora and fauna, but only humans. With reference to point } 2 \\
\text { above. This publication does not seem to have a facility where all } \\
\text { individual exposures via various corresponding individual exposure } \\
\text { routes, could be summed up to determine total exposure for a given } \\
\text { receptor exposed to a given hazard. Does not take account of statistical } \\
\text { aspects as indicated in point } 5 \text { above. }\end{array}$ \\
\hline Eduljee, 1998 & $\begin{array}{l}\text { A procedure on exposure assessment has been outlined } \\
\text { which covers elements like } 1 \text { and } 2 \text { (listed above) to } \\
\text { various levels of detail. However, only humans have been } \\
\text { considered as receptors. }\end{array}$ & $\begin{array}{l}\text { No computer model exists for the exposure assessment procedure in a } \\
\text { holistic manner. Elements } 3,4 \text { and } 5 \text { above are absent and element } 2 \text { is } \\
\text { addressed to a limited extent. The procedure presented excludes various } \\
\text { environmental receptors such as flora, fauna and the built environment. }\end{array}$ \\
\hline $\begin{array}{l}\text { Asante-Duah, } \\
1996\end{array}$ & $\begin{array}{l}\text { Encircles all important aspects of risk analysis and } \\
\text { management (including exposure assessment) of }\end{array}$ & Not specifically for landfills. Also all the elements above are absent. \\
\hline
\end{tabular}




\begin{tabular}{|c|c|c|}
\hline & $\begin{array}{l}\text { contaminated lands, but not in the form of a methodology. } \\
\text { The various aspects have been considered as independent } \\
\text { of each other. }\end{array}$ & \\
\hline $\begin{array}{l}\text { Daugherty, } \\
1998\end{array}$ & $\begin{array}{l}\text { Contains details not only of exposure but also those of } \\
\text { sources (of hazards), pathways and receptors in separate } \\
\text { chapters. }\end{array}$ & $\begin{array}{l}\text { This publication, like others, does not depict exposure assessment in the } \\
\text { form of a procedure that a risk assessor could use to measure exposure. } \\
\text { The publication is not specifically for landfills. Moreover, all the } \\
\text { elements above are absent. }\end{array}$ \\
\hline $\begin{array}{l}\text { Environment } \\
\text { Agency, 2003e }\end{array}$ & $\begin{array}{l}\text { This landfill risk assessment publication is from the } \\
\text { perspective of issues including noise, odour, litter, birds, } \\
\text { vermin, insects, and mud on road. }\end{array}$ & $\begin{array}{l}\text { The publication is not about landfill leachate in the first place. The } \\
\text { elements indicated in Row } 1 \text { above thus are not in the scope of the } \\
\text { publication. }\end{array}$ \\
\hline $\begin{array}{l}\text { Bernard et. al., } \\
\text { 1996; } 1997\end{array}$ & $\begin{array}{l}\text { These two papers (Part } 1 \text { and } 2 \text { ) are on hazard analysis of } \\
\text { landfill leachate. They discuss leachates from } 25 \text { landfills } \\
\text { in France as case studies with a number of methods of } \\
\text { determining leachate toxicity and then comparing the } \\
\text { physico-chemical characteristics of leachates. }\end{array}$ & $\begin{array}{l}\text { Although, the techniques identified on measuring toxicity of landfill } \\
\text { leachate can be useful in exposure assessment for a given landfill. But } \\
\text { these papers still are not to present procedures for exposure analysis and } \\
\text { the elements expressed above are not addressed in an integrated manner. }\end{array}$ \\
\hline EPD, 1997 & $\begin{array}{l}\text { This publication is a guideline for hazard analysis of } \\
\text { landfill gas. It briefly covers various aspects of hazard and } \\
\text { risk assessment such as hazard mitigation measures and } \\
\text { source-pathway-target analysis approach. }\end{array}$ & $\begin{array}{l}\text { The publication is not for landfill leachate. Even for landfill gas the } \\
\text { aforesaid elements are either completely absent or very few are partly } \\
\text { covered to limited extent (as mentioned in the left column). }\end{array}$ \\
\hline $\begin{array}{l}\text { Kavazanjian } \\
\text { et. al., 1995; } \\
\text { Eisenbeis, et. } \\
\text { al., } \quad 1986 \text {; }\end{array}$ & $\begin{array}{l}\text { In addition to other old literature on landfill assessment } \\
\text { discussed earlier in this paper, these were also investigated } \\
\text { to make sure if there was any work done on exposure } \\
\text { analysis, relatively further in the past. These have been }\end{array}$ & $\begin{array}{l}\text { These publications cover various aspects and factors of risk assessments } \\
\text { (including exposure analysis) to varying degrees. However, none of } \\
\text { them appear to present a holistic system of exposure assessment process } \\
\text { in a quantitative manner for landfill leachate, which could take account }\end{array}$ \\
\hline
\end{tabular}




\begin{tabular}{|c|c|c|}
\hline $\begin{array}{l}\text { Jaggy, } 1996 ; \\
\text { WDA, } 1994 ; \\
\text { LaGoy, 1994; } \\
\text { DOE, } 1994 ; \\
\text { and Pieper et. } \\
\text { al., } 1997 .\end{array}$ & $\begin{array}{l}\text { found to address various risk assessment issues like seismic } \\
\text { hazard analysis for landfills; risk assessment itself; landfill } \\
\text { type and nature; contaminated land remediation; hazardous } \\
\text { wastes; HWIR (Hazardous Waste Identification Rule); and } \\
\text { specific hazards such as polychlorinated dibenzo-p-dioxins } \\
\text { and furans (PCDD/F). }\end{array}$ & of all possible scenarios and elements indicated in Row 1 above. \\
\hline SEPA, 2002 & $\begin{array}{l}\text { This publication regards landfill risk assessment in the } \\
\text { context of landfill leachate liners and drainage systems. }\end{array}$ & $\begin{array}{l}\text { This publication is not to describe a strategic procedure to carry out } \\
\text { exposure assessment process in a quantitative manner. }\end{array}$ \\
\hline CPPD, 2004 & $\begin{array}{l}\text { Currently the publication is in a draft form. It regards } \\
\text { hazard and risk assessment in the context of natural hazards } \\
\text { such as flooding, earthquake, landslides, wildfire. }\end{array}$ & $\begin{array}{l}\text { The publication is not for anthropogenic activities in the first place. } \\
\text { Therefore does not consider landfills at all. Though discusses various } \\
\text { natural hazards with statistics but does not present a structured exposure } \\
\text { analysis procedure even for the natural hazards covered. }\end{array}$ \\
\hline $\begin{array}{l}\text { Rudland et. al., } \\
2001\end{array}$ & $\begin{array}{l}\text { Describes a basic framework for the risk assessment of } \\
\text { contaminated land. }\end{array}$ & Not for landfills in specific. All the elements above (Row 1) are absent. \\
\hline $\begin{array}{l}\text { Auckland } \\
\text { Regional } \\
\text { Council, } 2002\end{array}$ & $\begin{array}{l}\text { This publication, which is a government document for } \\
\text { local authorities, covers risk assessment in a very broad } \\
\text { sense of hazards. These include natural hazards such as } \\
\text { tornado, flooding, earthquake; technological hazards like } \\
\text { high pressure gas mains, computer systems failure; } \\
\text { biological hazards including disease amongst people, } \\
\text { animals or plants; and civil / political hazards comprising } \\
\text { terrorism and civil unrest. }\end{array}$ & $\begin{array}{l}\text { The publication is not specifically for landfills. It just encapsulates all } \\
\text { natural and anthropogenic hazards without presenting a holistic } \\
\text { procedure either for exposure assessment or risk analysis. The format is } \\
\text { more like a checklist. }\end{array}$ \\
\hline DOE, 1998 & This environmental guidance mentions Risk-Based & The purpose of this document is not the development of a holistic \\
\hline
\end{tabular}




\begin{tabular}{|c|c|c|}
\hline & $\begin{array}{l}\text { Corrective Action (RBCA) standards developed for } \\
\text { addressing petroleum and chemical releases. The purpose } \\
\text { of this guide is to explain risk-based decision making and } \\
\text { the RBCA process for environmental restoration of } \\
\text { chemically contaminated sites. }\end{array}$ & $\begin{array}{l}\text { exposure assessment methodology. The system presented is not for } \\
\text { landfills as such. The system emphasises more on determining the data } \\
\text { required for technical decision making rather than on following specific } \\
\text { steps of exposure assessment process as indicated in the aforesaid } \\
\text { elements in Row } 1 \text {. }\end{array}$ \\
\hline $\begin{array}{l}\text { EPA, } 1998 ; \\
\text { EPA, } 1996 \mathrm{a} ; \\
\text { 1996b; 1996c. }\end{array}$ & $\begin{array}{l}\text { These four documents are regarding risk assessments of } \\
\text { neurotoxicity, reproductive toxicity, ecology and } \\
\text { carcinogens, respectively. }\end{array}$ & $\begin{array}{l}\text { Though these documents may be useful in exposure assessment and risk } \\
\text { analysis of landfill leachate in the context of establishing neurotoxicity, } \\
\text { reproductive toxicity, ecological and carcinogenic affects of leachate } \\
\text { pollutants. However, these publications are not produced specifically } \\
\text { from the point of view of landfill leachate. Thus, there is no integrated } \\
\text { procedure to carry out exposure analysis process in a quantitative } \\
\text { manner for landfill leachate, which could take account of all possible } \\
\text { scenarios and the elements indicated above in Row } 1 \text {. }\end{array}$ \\
\hline $\begin{array}{l}\text { EPA, } \\
1999\end{array}$ & $\begin{array}{l}\text { These publications are purely for exposure assessment. } \\
\text { Thus, they encircle the subject from many different } \\
\text { perspectives including not only aspects of hazards, } \\
\text { pathways, receptors and exposures; but also types of doses } \\
\text { (e.g. potential dose, intake dose, applied dose), exposure } \\
\text { dose relationships, uncertainty assessment, individual and } \\
\text { population exposure, exposure analysis in epidemiological } \\
\text { studies, and position of the exposure assessment itself with } \\
\text { respect to risk characterisation. }\end{array}$ & $\begin{array}{l}\text { Although these publications focus purely on exposure assessment, the } \\
\text { documents do not portray a holistic procedure for carrying out exposure } \\
\text { analysis. Neither specifically for landfills nor for any other } \\
\text { environmental risk analysis. All the elements above (Row 1) are absent } \\
\text { in these publications from the landfill perspective. }\end{array}$ \\
\hline CMSA, 2004; & These publications are regarding hazard and risk & first place. All the \\
\hline
\end{tabular}




\begin{tabular}{|l|l|l|}
\hline Puncochar, & assessment in the context of these respective subjects: & aforesaid elements are absent from the landfill leachate perspective. \\
2003; Koivisto & mining, workplace, genetically modified organisms, & \\
et. al., 2001; & neurology, indoor environment, ecology, toxicology, food, & \\
Feldman and & and chemicals. & \\
White, 1996; & & \\
CHEM Unit, & & \\
2003; Pauluhn, & & \\
1999; Muth et. & & \\
al., $2001 ;$ & & \\
Tarazona and & & \\
Vega, 2002 & & \\
\hline
\end{tabular}


Figure 1: The Waste Hierarchy - The arrow points from the least preferred waste management option to the topmost priority (DoE and Welsh Office, 1995a; 1995b; SITA, 2004; Envirowise, 2005; SEPA, 2008)

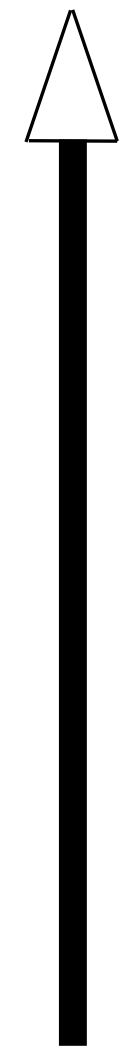

\section{PREVENTION \\ REDUCTION}

RE-USE

\section{RECOVERY}

- Recycling

- Composting

- Energy (recovered from the waste incineration, landfill gas combustion)

\section{DISPOSAL}

- Incineration without energy recovery

- Landfill without gas energy recovery 
Figure 2: The Exposure Assessment Framework in relation to overall Risk Assessment Structure (Adapted, derived and concluded from the work of various authors including Peacock and Whyte, 1992; WDA, 1994; Tweeds, 1996; WHO, 1997; EPA, 2000; TOSC, 2000; CIRIA, 2001; Viswanathan et. al., 2002; CMSA, 2004)

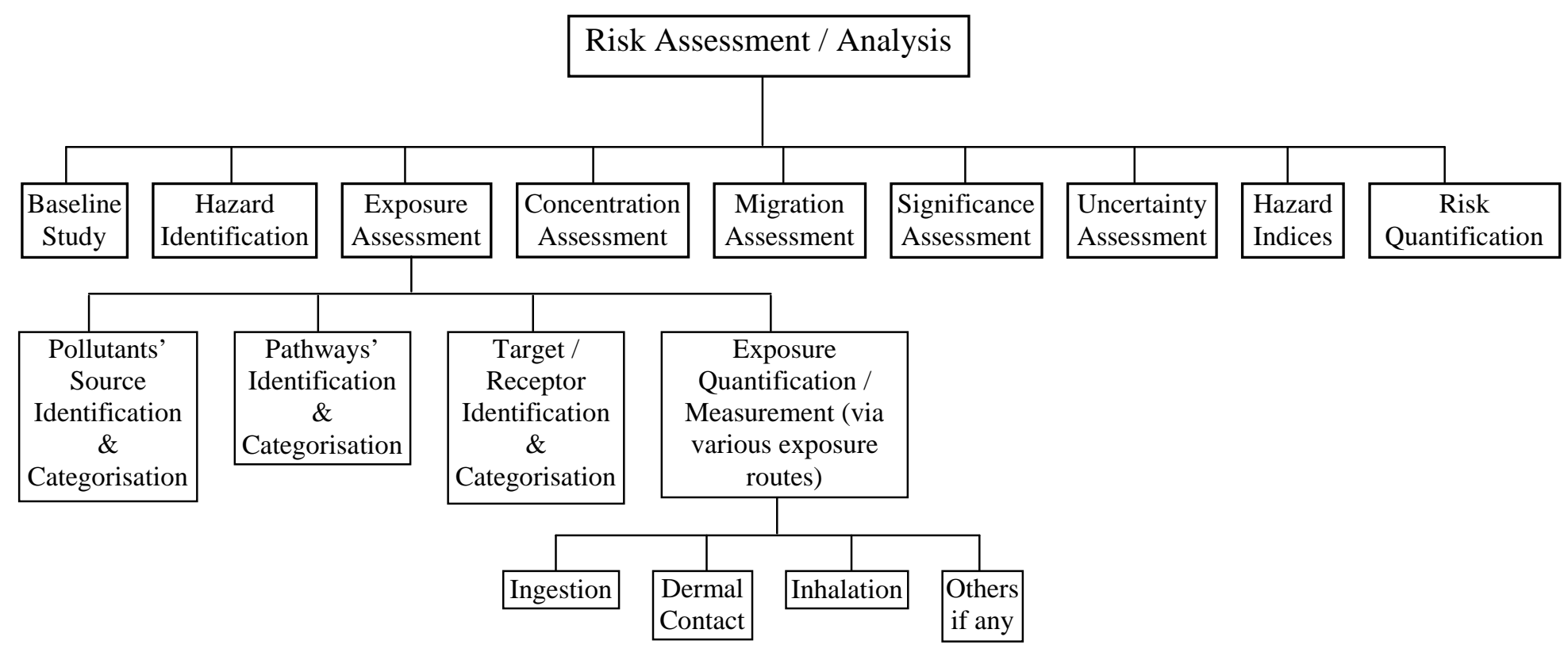

